\title{
Regional earning disparities and the speed of transition: evidence from Poland 1994-1997
}

\author{
Fiona Burke ${ }^{1 *}$ and Patrick Paul Walsh ${ }^{2}$
}

\footnotetext{
* Correspondence: burkef@itcarlow. ie

'Department of Management Studies, IT Carlow, Carlow, Ireland Full list of author information is available at the end of the article
}

\begin{abstract}
In the early days of transition Poland hosted regional earning disparities. Low levels of worker and firm mobility allow us to threat regions as local labor markets. Wage behavior is modeled in regional labor markets as an outcome of the speed of transition examining employment restructuring in labor demand. The local shortterm unemployment (excessive layoffs) rate elasticity of pay is estimated as -0.29 and the local annual hiring rate elasticity of pay as +0.75 , controlling for individual characteristics and selection, amongst other factors. While individual characteristics determine participation rates and where one is on the wage distribution within regions, employment restructuring accounts for most of the mean earning disparities across regions.

Journal of Economic Literature: Classification Numbers J6, L0 and O5.

Keywords: Earnings, Speed of transition and polish regions
\end{abstract}

"If several workmen were to be asked: 'How much wages do you get?' one would reply, 'I get two shillings a day', and so on. According to the different branches of industry in which they are employed, they would mention different sums of money that they receive from their respective employers for the completion of a certain task; for example, for weaving a yard of linen, or for setting a page of type. Despite the variety of their statements, they would all agree upon one point: that wages are the amount of money which the capitalist pays for a certain period of work or for a certain amount of work; it is the capitalist who determines wages." (Marx, 1933 pp17)

\section{Introduction}

At the start of transition, labor market conditions were characterized by full employment of the working age population in inefficient enterprises across oversized industrial and agricultural sectors. In moving to a market economy many researchers anticipated unprecedented worker reallocation. The expansion of services and downsizing of manufacturing and agriculture would have to be facilitated by worker reallocation. In addition, the downsizing, exit and entry of enterprises within sectors would also have to be accommodated by further worker reallocation. Aghion and Blanchard (1994), present us with a model of wage setting within an Optimal Speed of Transition (OST) model of worker reallocation. ${ }^{1}$ The government dictates the optimal speed at which workers are released from non-restructured enterprises. ${ }^{2}$ To increase the speed of absorption of labor into the

(c) 2012 Walsh and Burke; licensee Springer. This is an Open Access article distributed under the terms of the Creative Commons Attribution License (http://creativecommons.org/licenses/by/2.0), which permits unrestricted use, distribution, and reproduction in any medium, provided the original work is properly cited. 
restructured sector, unemployment (benefits) can be used to maintain a downward pressure on wages. The extent to which unemployment can be used is constrained by having unemployment benefits financed out of labor taxes. Unemployment levels can determine the speed of labor reallocation. The model predicts an optimal layoff rate in each period that maximizes the hiring rate in restructured enterprises. Average pay in a labor market is predicted to be negatively related to the unemployment (excessive layoffs) rate and positively related to the annual hiring rate. Their theoretical model relates the level of pay to the speed of worker reallocation. The pace of employment restructuring should be a key determinant of the mean wage, amongst other factors ${ }^{3}$. This theory is tested across forty-nine local Polish labor markets during the early phase of transition.

This paper conducts individual regressions, assuming individual pay does not dictate regional annual worker reallocation, and estimates the, on average, impact of the speed of transition on pay, controlling for a rich set of individual characteristics and the selection process into employment, among other factors. To show the appropriateness of this approach several questions are addressed; Is it right to threat Polish regions as local labor markets? Was there a regional variation in short-term unemployment and hiring rates across regions in early transition? and finally, Was there a regional disparity in mean pay during early transition?

The lack of inter-regional worker and job flows during transition is well documented for Poland. Deichmann and Henderson (2000) document increasing wage differentials and persistent differentials in unemployment rates across regions, even amongst neighboring regions in Poland during the period 1990-1998. One might have expected migration flows to increase dramatically during transition, but a dramatic slowdown is documented. They put forward housing shortages as a key deterrent of migration. The absence of migration flows ensures that the authors do not have to concern ourselves with the standard HarrisTodaro critique, the need to model migration as a key labor supply determinant of regional wage levels. In addition, inter-regional job flows have been virtually absent during transition (see Faggio and Konings, 2003). Firm migration has not been a key feature of regional labor demand. It is assumed assume that workers and firms are locked into local labor markets during the period of our analysis, 1994-1996 ${ }^{4}$.

Why should the optimal speed of worker reallocation be expected to differ across local labor markets in Poland? Local labor markets in Poland inherited very idiosyncratic employment structures coming out of planning that have persisted. While most regions, by western standards, had a narrow range of employment activities, some eastern regions were extremely specialized. This is apparent in Table 1, which documents the regional concentration of employment by 2 -digit sectors (shown in annex 1 ). The $\mathrm{C} 1$ concentration ratio illustrates that the biggest 2-digit sectors can account for as much as 60 per cent of total regional employment, while the C5, top five 2-digit sectors, accounts for the vast majority of regional employment. As a result of such initial conditions in employment structure the optimal speed of transition did differ across labor markets ${ }^{5}$. In Table 2 the gaps in annual short-term unemployment (excessive layoffs) and hiring rates relative to Warsaw are documented. Such regional disparities in annual worker flows should reflect the speed of ongoing regional restructuring (or lack off) of traditional enterprises and the expansion (or lack off) of new enterprises.

Finally regional disparities in mean pay are examined. In the first two columns of Table 3 the mean monthly wage (thousands of Polish Zloty) across regions calculated 
Table 1 Concentration ratios of employment into the top1, 2, 5 and 10 2-digit sectors (Average 1994-1996)

\begin{tabular}{|c|c|c|c|c|}
\hline Region & $\mathrm{C} 1$ & $\mathrm{C} 2$ & C5 & $\mathrm{C} 10$ \\
\hline Bialostockie & 48 & 59 & 81 & 93 \\
\hline Bialskopodlaskie & 34 & 48 & 71 & 84 \\
\hline Bielskie & 14 & 23 & 47 & 69 \\
\hline Bydgoskie & 16 & 28 & 51 & 74 \\
\hline Chelmskie & 44 & 53 & 71 & 92 \\
\hline Ciechanowskie & 45 & 54 & 72 & 88 \\
\hline Czestochowskie & 20 & 31 & 56 & 75 \\
\hline Elblaskie & 17 & 29 & 54 & 79 \\
\hline Gdanskie & 16 & 30 & 60 & 80 \\
\hline Gorzowskie & 14 & 28 & 54 & 78 \\
\hline Jeleniogorskie & 14 & 26 & 52 & 74 \\
\hline Kaliskie & 29 & 38 & 60 & 80 \\
\hline Katowickie & 33 & 44 & 66 & 81 \\
\hline Kieleekie & 41 & 49 & 70 & 83 \\
\hline Koninskie & 26 & 38 & 65 & 84 \\
\hline Koszalinskie & 16 & 27 & 55 & 83 \\
\hline Krakowskie & 21 & 37 & 64 & 81 \\
\hline Krosnienskie & 18 & 34 & 51 & 71 \\
\hline Legnickie & 18 & 33 & 63 & 82 \\
\hline Leszezynskie & 21 & 35 & 64 & 85 \\
\hline Lodzkie & 36 & 45 & 67 & 84 \\
\hline Lomzynskie & 56 & 63 & 79 & 92 \\
\hline Lubelskie & 16 & 29 & 52 & 75 \\
\hline Nowosadeckie & 43 & 53 & 71 & 86 \\
\hline Olsztynskie & 20 & 39 & 51 & 82 \\
\hline Opolskie & 16 & 27 & 51 & 73 \\
\hline Ostroleckie & 42 & 51 & 72 & 87 \\
\hline Pilskie & 17 & 29 & 57 & 73 \\
\hline Piotrkowskie & 31 & 43 & 62 & 82 \\
\hline Plockie & 35 & 44 & 65 & 84 \\
\hline Poznanskie & 13 & 24 & 49 & 75 \\
\hline Premyskie & 34 & 45 & 64 & 83 \\
\hline Radomskie & 35 & 44 & 62 & 81 \\
\hline Rzeszowskie & 32 & 44 & 66 & 83 \\
\hline Siedleckie & 40 & 49 & 68 & 84 \\
\hline Sieradzkie & 40 & 54 & 67 & 83 \\
\hline Skierniewickie & 31 & 43 & 63 & 86 \\
\hline Slupskie & 13 & 28 & 52 & 81 \\
\hline Suwalskie & 34 & 44 & 65 & 86 \\
\hline Szezecinskie & 15 & 30 & 57 & 79 \\
\hline Tarnobrzeskie & 42 & 50 & 69 & 86 \\
\hline Tarnowskie & 38 & 48 & 67 & 85 \\
\hline Torunskie & 23 & 34 & 57 & 81 \\
\hline
\end{tabular}


Table 1 Concentration ratios of employment into the top1, 2, 5 and 10 2-digit sectors (Average 1994-1996) (Continued)

\begin{tabular}{lllll}
\hline Walbrzyskie & 11 & 21 & 46 & 70 \\
Warszawskie & $\mathbf{2 1}$ & $\mathbf{3 4}$ & $\mathbf{5 7}$ & $\mathbf{7 8}$ \\
Wloclawskie & 50 & 58 & 71 & 89 \\
Wroclawskie & 14 & 26 & 53 & 72 \\
Zamojskie & 60 & 66 & 78 & 92 \\
Zielonogorskie & 13 & 24 & 48 & 76 \\
\hline
\end{tabular}

(Source: Calculations based on Polish LFS).

for males from the November wave of the Labor Force Survey (LFS) is documented. To understand how representative the LFS data is the authors document the mean monthly wage across regions taken from Polish regional yearbooks ${ }^{6}$. Even though the level of wages is higher in official data, the trends over-time and across regions are similar. It is observed that the gap between pay in regions relative to Warsaw is persistent. On average, pay outside Warsaw is 30 per cent lower.

The main aim of this paper is to explain regional disparity in mean pay during early transition. Motivated by Aghion and Blanchard (1994) the authors consider the role of unemployment and hiring rates across regions as a determinant of regional pay disparities, controlling for a rich set of individual characteristics and the selection process into employment, amongst other factors. Using this strategy the local short-term unemployment (excessive layoffs) and annual hiring rate elasticity of individual pay is estimated to be approximately -0.29 and +0.75 , respectively. Large regional variation in short-term unemployment and hiring rates ensure that the speed of transition explains most of the disparity in average earnings across regions. Yet, individual characteristics are important for participation and where one is on the wage distribution within regions.

\section{Wage behavior during transition}

The model in this section is the basic labor reallocation model of Aghion and Blanchard (1994), as illustrated in Roland (2000). The labor force in a labor market is normalized to 1. The number of workers in restructured firms in date $t$ is $N_{R}(t)$, the number of workers in an non-restructured state at date $t$ is $N_{N R}(t)$, and the number of unemployed job searchers at date $t$ is $U(t)$.

$$
N_{R}(t)+N_{N R}(t)+U(t)=1
$$

The objective of the government is to decide on the optimal number of worker flows from the non-restructured state in each time period, $d N_{N R}^{*}(t) / d t$, in full anticipation of the factors that determine the speed of reallocation ${ }^{7}$. Increases in employment in restructured firms in date $t, d N_{R}(t) / d t$, is determined by the following equation,

$$
\frac{d N_{R}(t)}{d t}=\delta[1-(w(t)+z(t))]
$$

The marginal revenue product of labor is normalized to 1 . The marginal cost of labor is made up of a wage rate, $w(t)$, and a tax, $z(t)$, in time $t$ levied on wages to finance unemployment benefits. The value of $\delta$ is the scale of operation of the restructured sector. This determines how many workers are employed in time $t$ given the mark-up on one unit 
Table 2 Persistent gaps in annual STU and hiring rates across regions

\begin{tabular}{|c|c|c|c|c|c|c|c|c|c|c|c|c|}
\hline \multirow[b]{3}{*}{ Regions } & \multirow{2}{*}{\multicolumn{3}{|c|}{$\frac{\text { Annual STU Rate }}{\text { Labor Force Survey }}$}} & \multirow{2}{*}{\multicolumn{3}{|c|}{$\frac{\text { Relative to Warsaw }}{\text { Labor Force Survey }}$}} & \multirow{2}{*}{\multicolumn{3}{|c|}{$\frac{\text { Annual Hiring Rate }}{\text { Labor Force Survey }}$}} & \multirow{2}{*}{\multicolumn{3}{|c|}{$\frac{\text { Relative to Warsaw }}{\text { Labor Force Survey }}$}} \\
\hline & & & & & & & & & & & & \\
\hline & 1994 & 1995 & 1996 & 1994 & 1995 & 1996 & 1994 & 1995 & 1996 & 1994 & 1995 & 1996 \\
\hline alostockie & 04 & 然 & (1) & 0.98 & 1.09 & (1.0 & 0. & 0.10 & 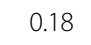 & - & 0.64 & 076 \\
\hline (at & 0.05 & 0.05 & 0.05 & 1.15 & 1.32 & 1.71 & 0.18 & 0.15 & 0.19 & 0.75 & 0.61 & 0.7 \\
\hline elskie & 0.04 & 0.05 & 0.04 & 0.97 & 1.19 & 1.46 & 0.23 & 0.22 & 0.21 & 0.98 & 0.91 & 0.8 \\
\hline Bydgoskie & 0.08 & 0 & 0 & 1 & 2 & 2 & 5 & 0 & 0.24 & 9 & 4 & (0 \\
\hline 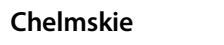 & 0.06 & 0.04 & 0.06 & 1.28 & 0.93 & 1.97 & 0.17 & 0.12 & 0.17 & 0.72 & 0.51 & 0.7 \\
\hline 2 & 0 & (707 & 0.07 & 1 & 1. & 2 & 0 & 0 & 0 & 085 & 0.97 & 08 \\
\hline Cotor & 0.09 & 0.04 & 0.06 & 2.03 & 0.99 & 2.12 & 0.13 & 0.19 & 0.24 & 0.55 & 0.76 & 0.9 \\
\hline 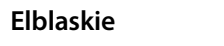 & 009 & 0.09 & 0.03 & 2 & 2. & 1.03 & 0. & 0. & 0.29 & 1.00 & 0 & 1.19 \\
\hline (1) & 0.06 & 0.05 & 0.05 & 1.35 & 1. & 1.63 & 0. & 0.25 & 0.25 & 0. & 1 & 1.0 \\
\hline 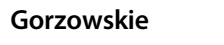 & 0 & 0.09 & 0.09 & 2.83 & 2.13 & 2.98 & 0.19 & 0.25 & 0.32 & 0.79 & 1.04 & 1.3 \\
\hline Jeleniogorsk & 0.08 & 0.13 & 0 & 1.73 & 3 & 3. & 0.23 & 0 & 0. & 0. & 1.07 & 1.13 \\
\hline Kaliskie & 0.06 & 0.06 & 0.06 & 1.25 & 1.41 & 2.02 & 0.19 & 0.17 & 0.18 & 0.80 & 0.70 & 0.7 \\
\hline Katowick & 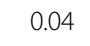 & 0.03 & 0 & 0 & 0. & 1.12 & 0. & 0 & 017 & 0.67 & 0.76 & 0.69 \\
\hline eleekie & 0.00 & 0.07 & 0.05 & 1. & 1. & 1.56 & 0. & 0.17 & 0.18 & 0.63 & 0 & 0.7 \\
\hline 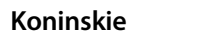 & 07 & 0.06 & 0.09 & 1 & 1.44 & 2.90 & 3 & 0 & 0.20 & 0.56 & 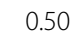 & 08 \\
\hline & 0.11 & 0.12 & 0 & & 3. & 4 & 0 & 0 & 0 & 1.23 & & e \\
\hline skie & 0.05 & 0.05 & 0.03 & 1.06 & 1.14 & 1.01 & 0.19 & 0.17 & 0.19 & 0.82 & 0.71 & 0.7 \\
\hline & 0.03 & 0.09 & 0.06 & & $2+2$ & 1 & 0.22 & 0.16 & 0.17 & 0.93 & & 0.71 \\
\hline Legn & vo & 0.08 & 0.05 & 1 & 1.91 & 1.64 & 0.15 & 0.14 & 0.22 & 0.63 & 0.59 & 0.89 \\
\hline ( & 然 & 0.05 & 0.05 & 1 & 1.2 & 1.50 & 0 & 0.2 & 0.23 & 05 & 1.00 & 0.9 \\
\hline Lodzkie & 0.04 & 0.06 & 0 & 0 & 1 & 1 & 0.17 & 0.15 & 0.18 & 0.70 & 0.60 & 0.76 \\
\hline & 05 & 0.06 & 0.04 & 1. & 1.49 & 1.46 & 0. & 0. & 0.18 & 0.74 & 0. & 0.7 \\
\hline & 0.09 & 0 & 0 & $2+2$ & 2 & $2+2$ & 0.21 & 0 & 0.21 & 0 & 0.90 & 086 \\
\hline Nowos & 0.04 & 0.05 & 0.08 & 0.98 & 1.18 & 2.70 & 0.15 & 0.17 & 0.22 & 0.62 & 0.69 & 0.9 \\
\hline Olsztynskie & 0.10 & 0.09 & 0. & $2+2$ & 2 & 3. & 0 & 0. & 0 & 0. & 0 & 0.9 \\
\hline Opolskie & 0.05 & 0.06 & 0.04 & & 1.40 & 1.45 & & & 0.19 & 0.81 & 8 & 0.80 \\
\hline Ostrole & 0.09 & 0.10 & 0.05 & 1.91 & 2.37 & 1.56 & 0.20 & 0.17 & 0.23 & 0.84 & 0.69 & 0.94 \\
\hline & 0.10 & 0.00 & 0.0 & & 2 & 1 & 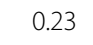 & 0. & 0.25 & 0.98 & 0.82 & 103 \\
\hline 年 & 0.08 & 0.05 & 0.07 & 1.85 & 1.33 & 2.24 & 0.16 & 0.20 & 0.17 & 0.66 & 0.81 & 0.71 \\
\hline Plockie & 0.06 & 0.06 & 0 & 1.42 & 1 & 5 & 0 & 0 & 0.15 & 0.85 & 3 & 0.61 \\
\hline Poznanskie & 0.05 & 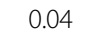 & 0 & 1 & 1. & 1. & v. & 0. & 0 & 6 & 0.90 & 0.79 \\
\hline кie & 0.06 & 0.06 & 0.05 & 1.43 & 1.49 & 1.78 & 0.10 & 0.13 & 0.15 & 0.44 & 0.55 & 0.61 \\
\hline Radomskie & 0.06 & 0.08 & 0.05 & 1.38 & 1.86 & 1 & 0.15 & 0.18 & 0.16 & 0.65 & 0.73 & 0.66 \\
\hline NLESZOUWSK & 0.05 & 0.06 & 0.07 & 1.01 & 1.42 & 2.21 & 0.19 & 0.20 & 0.22 & 0.79 & 0.82 & 0.8 \\
\hline e & 06 & 0.05 & 0.04 & $14+2+$ & 1.15 & 133 & 0 & 0.19 & 018 & 0.80 & 0 & 0.75 \\
\hline Sieradzkie & No & 0.09 & 0.04 & 1.73 & 2.13 & 1.36 & 0 & 0. & 0.11 & 0.73 & 0.67 & . \\
\hline Sk & 10 & 0.02 & 0.03 & 2.18 & 0.45 & 0.86 & 0.17 & 0.18 & 0.21 & 0.72 & 0.75 & 86 \\
\hline Slupskie & 0.18 & 0 & 0 & 3.94 & 9 & 9 & 9 & 0 & 28 & 0.81 & 1.03 & 1.14 \\
\hline suwaiskie & 0.13 & 0.12 & 0.11 & 2.79 & 2.86 & 3.65 & 0.16 & 0.19 & 0.21 & 0.69 & 0.77 & 0.8 \\
\hline (2) & 1 & 5 & 0.06 & 2.38 & 1.11 & 8 & 0.21 & 0.27 & 0.24 & 0.86 & 1.12 & 1.00 \\
\hline arnobrzeskie & 0.05 & 0.06 & 0.04 & 1.09 & 1.54 & 1.48 & 0.12 & 0.17 & 0.14 & 0.51 & 0.70 & 0.59 \\
\hline arnowskie & 0.06 & 0.06 & 0.03 & 1.37 & 1.34 & 1.07 & 0.16 & 0.19 & 0.24 & 0.66 & 0.79 & 1.0 \\
\hline
\end{tabular}


Table 2 Persistent gaps in annual STU and hiring rates across regions (Continued)

\begin{tabular}{lrrrrrrrrrrrr}
\hline Torunskie & 0.08 & 0.07 & 0.08 & 1.88 & 1.73 & 2.74 & 0.20 & 0.19 & 0.22 & 0.84 & 0.79 & 0.88 \\
Walbrzyskie & 0.10 & 0.08 & 0.10 & 2.21 & 1.90 & 3.27 & 0.17 & 0.20 & 0.20 & 0.72 & 0.83 & 0.84 \\
Warszawskie & 0.04 & 0.04 & 0.03 & 1.00 & 1.00 & 1.00 & 0.24 & 0.24 & 0.24 & 1.00 & 1.00 & 1.00 \\
Wloclawskie & 0.09 & 0.11 & 0.08 & 1.94 & 2.68 & 2.57 & 0.19 & 0.15 & 0.16 & 0.79 & 0.63 & 0.66 \\
Wroclawskie & 0.05 & 0.06 & 0.06 & 1.19 & 1.48 & 1.85 & 0.25 & 0.25 & 0.25 & 1.05 & 1.02 & 1.02 \\
Zamojskie & 0.05 & 0.06 & 0.04 & 1.05 & 1.34 & 1.28 & 0.15 & 0.16 & 0.21 & 0.61 & 0.65 & 0.85 \\
Zielonogorskie & 0.08 & 0.11 & 0.06 & 1.81 & 2.75 & 1.83 & 0.18 & 0.24 & 0.23 & 0.74 & 0.99 & 0.95 \\
Mean & $\mathbf{0 . 0 7}$ & $\mathbf{0 . 0 7}$ & $\mathbf{0 . 0 6}$ & $\mathbf{1 . 6 2}$ & $\mathbf{1 . 6 7}$ & $\mathbf{2 . 0 1}$ & $\mathbf{0 . 1 8}$ & $\mathbf{0 . 2 0}$ & $\mathbf{0 . 2 1}$ & $\mathbf{0 . 7 7}$ & $\mathbf{0 . 8 0}$ & $\mathbf{0 . 8 6}$ \\
SD & $\mathbf{0 . 0 2 8}$ & $\mathbf{0 . 0 2 6}$ & $\mathbf{0 . 0 2 4}$ & $\mathbf{0 . 6 2 2}$ & $\mathbf{0 . 6 2 5}$ & $\mathbf{0 . 8 0 9}$ & $\mathbf{0 . 0 3 7}$ & $\mathbf{0 . 0 4 0}$ & $\mathbf{0 . 0 3 8}$ & $\mathbf{0 . 1 5 7}$ & $\mathbf{0 . 1 6 4}$ & $\mathbf{0 . 1 5 6}$ \\
Min & $\mathbf{0 . 0 3}$ & $\mathbf{0 . 0 2}$ & $\mathbf{0 . 0 3}$ & $\mathbf{0 . 6 2}$ & $\mathbf{0 . 4 5}$ & $\mathbf{0 . 8 6}$ & $\mathbf{0 . 1 0}$ & $\mathbf{0 . 1 2}$ & $\mathbf{0 . 1 4}$ & $\mathbf{0 . 4 4}$ & $\mathbf{0 . 5 0}$ & $\mathbf{0 . 5 9}$ \\
Max & $\mathbf{0 . 1 8}$ & $\mathbf{0 . 1 3}$ & $\mathbf{0 . 1 4}$ & $\mathbf{3 . 9 4}$ & $\mathbf{3 . 1 3}$ & $\mathbf{4 . 4 9}$ & $\mathbf{0 . 2 9}$ & $\mathbf{0 . 2 8}$ & $\mathbf{0 . 3 2}$ & $\mathbf{1 . 2 3}$ & $\mathbf{1 . 1 6}$ & $\mathbf{1 . 3 1}$ \\
\hline
\end{tabular}

of labor. Factors outside the labor market (such as the quality of public infrastructure) determine the size of $\delta$. The budget constraint of the government is given by,

$$
b U(t)=(1-U(t)) z(t)
$$

where $b$ is the per capita level of unemployment benefit that is assumed to be time invariant. As illustrated in Roland (2000), one can write down asset equations for the expected discounted (with $\rho$ ) income stream from unemployment and from employment in the restructured sector. Assuming there has to be a constant compensating differential, $c$, to induce people out of unemployment into the restructured sector, one can write the following reduced form expression for wage setting,

$$
w(t)=b+c\left(\rho+\frac{d N_{R}(t) / d t}{U(t)}\right)
$$

The above expression forms the basis of this paper's empirical work ${ }^{8}$. Pay is driven by outside options. In particular, it is negatively related to the unemployment rate (excessive layoffs during period ( $t$ ) that are effective job searchers) and positively related to the hiring rate during period ( $\mathrm{t})$ in the restructured firms. The variables $W(t), d N_{R}(t) / d t$, and $U(t)$ are endogenous outcomes.

The government is assumed to control the optimal number of separations coming from non-restructured firms, $d N_{N R}^{*}(t) / d t$, in period $t$. Market forces will determine the hiring rate, $d N_{R}(t) / d t$, and the unemployment rate, $U(t)$. The objective of the government is to maximize the speed of the reallocation process, by maximizing $d N_{R}(t) / d t$. Using equations (1) to (4) one can express $d N_{R}(t) / d t$ as the following,

$$
\frac{d N_{R}(t)}{d t}=\frac{\delta U(t)}{U(t)+c \delta}\left[1-\rho c-\frac{b}{1-U(t)}\right]
$$

In Figure 1 , the inverse $U$ relationship between the hiring rate, $d N_{R}(t) / d t$, and the unemployment rate, $U(t)$ is graphed. Clearly from equation (4) if $U(t)=0$, wages would be infinite and no reallocation can take place. In addition the hiring rate in the restructured sector is zero when, $U(t)=1-(b / 1-\rho c)$ : unemployment is so high that the tax on employment to finance unemployment benefits reduces the speed of reallocation to zero. The maximum speed of transition $d N^{*}{ }_{R}(t) / d t$ and associated $U^{*}(t)$ are illustrated in Figure 1. Knowing $d N_{R}(t) / d t$ and $U(t)$, one can back out the wage level from 
Table 3 Persistent gaps in mean monthly wages across regions

\begin{tabular}{|c|c|c|c|c|c|c|c|c|c|c|c|c|}
\hline \multirow[b]{3}{*}{ Regions } & \multirow{2}{*}{\multicolumn{3}{|c|}{$\begin{array}{l}\text { Mean Monthly } \\
\text { Wage }\end{array}$}} & \multirow{2}{*}{\multicolumn{3}{|c|}{$\begin{array}{l}\text { Relative to Warsaw } \\
\text { Labor Force Survey }\end{array}$}} & \multirow{2}{*}{\multicolumn{3}{|c|}{$\begin{array}{c}\text { Mean Monthly } \\
\text { Wage } \\
\text { Regional Yearbook }\end{array}$}} & \multirow{2}{*}{\multicolumn{3}{|c|}{$\begin{array}{l}\text { Relative to Warsaw } \\
\text { Regional Yearbook }\end{array}$}} \\
\hline & & & & & & & & & & & & \\
\hline & 1994 & 1995 & 1996 & 1994 & 1995 & 1996 & 1994 & 1995 & 1996 & 1994 & 1995 & 1996 \\
\hline 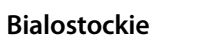 & ה בנכה & 470 & ( & 0.07 & & 4 & 1 & 5 & 738 & 0.68 & 0.67 & 0.65 \\
\hline Ialskop & 366 & 512 & 669 & 0.74 & 0.72 & 0.72 & 477 & 628 & 784 & 0.73 & 0.72 & 0.69 \\
\hline elskie & 39 & 535 & 764 & 0.80 & 0 & 0.82 & 489 & 6 & 808 & 4 & 4 & 0.71 \\
\hline ag & 386 & 582 & 746 & .78 & 0.82 & 0.80 & 482 & 634 & 800 & 0.73 & 0.72 & 0.71 \\
\hline helmskie & 340 & 490 & 718 & 0.69 & 0.69 & 0.77 & 441 & 593 & 748 & 0.67 & 0.68 & 0.66 \\
\hline Ecrianto & 3 & 508 & 681 & 0. & 0 & 0 & 4 & 5 & 713 & 0.66 & 0.65 & 0.63 \\
\hline Czestoch & 359 & 502 & 654 & 0.72 & 0.70 & 0.70 & 437 & 585 & 741 & 0.67 & 0.67 & 0.66 \\
\hline Elblaskie & 3 & 545 & 65 & 0.7 & 0 & 0 & 4 & 623 & 802 & 0 & 0 & 0.71 \\
\hline idanskie & 436 & 661 & 844 & 0.88 & 0.93 & 0.90 & 522 & 692 & 873 & 0.79 & 0.79 & 0.77 \\
\hline te & 393 & 501 & 709 & 0.79 & 0.70 & 0.76 & 457 & 606 & 757 & 0.69 & 0.69 & 0.67 \\
\hline It & 432 & 579 & 662 & 0.87 & 0.81 & 0. & 513 & 678 & 827 & 0.78 & 0.77 & 0.73 \\
\hline aliskie & 342 & 495 & 624 & 0.69 & 0.69 & 0.67 & 4 & 577 & 733 & 0.67 & 0.66 & 0.65 \\
\hline Katowickie & 5 & 68 & 90 & 1. & 0 & 0 & 6 & 860 & 1061 & 1. & 0.98 & 0.94 \\
\hline Kieleekie & 353 & 478 & 671 & 0.71 & 0.67 & 0.72 & 459 & 606 & 770 & 0.70 & 0.69 & 0.68 \\
\hline Koninskie & 422 & 5 & 711 & 0.85 & 3 & 0 & 5 & 7 & 887 & 0.86 & 0.83 & 0.78 \\
\hline Koszalinskie & 34 & 509 & 717 & 0.70 & 0. & 0.77 & 45 & 6 & 746 & 0.69 & 0.68 & 0.66 \\
\hline Krakowskie & 435 & 593 & 726 & 0.88 & 0.83 & 0.78 & 509 & 669 & 881 & 0.77 & 0.76 & 0.78 \\
\hline 政 & 32 & 471 & 631 & 0.66 & 0 & 0.68 & 4 & 595 & 747 & 0.68 & 0.68 & 0.66 \\
\hline kie & 443 & 580 & 765 & 0.89 & 0.81 & 0.82 & 607 & 816 & 1011 & 0.92 & 0.93 & 0.89 \\
\hline sons & 31 & 453 & 634 & 0.0 & 0.64 & 0. & 4 & 5 & 4 & 0 & 0 & 0.64 \\
\hline oazkie & 392 & 565 & 750 & 0.79 & 0.79 & 0.80 & 494 & 647 & 839 & 0.75 & 0.74 & 0.74 \\
\hline Lomz & 360 & 505 & 650 & 0.73 & 0.71 & 0.70 & 441 & 588 & 751 & 0.67 & 0.67 & 0.66 \\
\hline Lubelskie & 410 & 3 & 0 & 0.83 & 0.73 & 0.73 & 479 & 631 & t & J & 0.72 & 0.71 \\
\hline Nowo & 336 & 450 & 582 & 0.68 & 0.63 & 0.62 & 425 & 553 & 699 & 0.65 & 0.63 & 0.62 \\
\hline 然. & 政 & 516 & 699 & 0.17 & 0.7 & 0.7 & 47 & 61 & 775 & 0.72 & 0. & 0.69 \\
\hline (2) & 377 & 574 & 802 & 0.76 & 0.81 & 0.86 & 487 & 650 & 825 & 0.74 & 0.74 & 0.73 \\
\hline $\operatorname{tr}$ & 393 & 492 & 671 & 0.79 & 0.69 & 0.72 & 482 & 645 & 805 & 0.73 & 0.74 & 0.71 \\
\hline Pilskie & 361 & 5 & 0 & 0.73 & 0.73 & 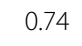 & 443 & 3 & 745 & 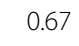 & 0 & 0.66 \\
\hline Piotrkow & 466 & 524 & 664 & 0.94 & 0.74 & 0.71 & 531 & 676 & 834 & 0.81 & 0.77 & 0.74 \\
\hline Plockie & 440 & 50 & 76 & 08 & 0 & 0 & 5 & 7 & $8-2-1$ & 0 & 0. & 0.78 \\
\hline 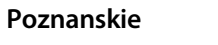 & 393 & 523 & 717 & .19 & 0 & 0.77 & 503 & 669 & 873 & 0.77 & 0.76 & 0.77 \\
\hline Premyskie & 296 & 421 & 656 & 0.60 & 0.59 & 0.70 & 440 & 583 & 731 & 0.67 & 0.67 & 0.65 \\
\hline Radomskie & 3 & 47 & 6 & 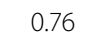 & 0 & 0 & 447 & 5 & 7 & 8 & 0 & 0.66 \\
\hline wskie & 352 & 495 & 650 & 0.71 & 0.69 & 0.70 & 466 & 618 & 784 & 0.71 & 0.70 & 0.69 \\
\hline Ddockin & 366 & 531 & 702 & 074 & 074 & 075 & 454 & 502 & 740 & 0.69 & 0.68 & 0.65 \\
\hline kie & 338 & 446 & 650 & 0.68 & 0.63 & 0.70 & 442 & 573 & 718 & 0.67 & 0.65 & 0.63 \\
\hline Skie & 378 & 488 & 626 & 0.76 & 0.69 & 0.67 & 439 & 594 & 750 & 0.67 & 0.68 & 0.66 \\
\hline$\therefore$ & $3 / 9$ & 479 & 686 & 0.76 & 0.6 & 0. & 43 & 57 & 712 & 0.66 & 0.65 & 0.63 \\
\hline Suwalskie & 341 & 510 & 723 & 0.69 & 0.72 & 0.77 & 436 & 579 & 733 & 0.66 & 0.66 & 0.65 \\
\hline inskie & 444 & 560 & 797 & 0.89 & 0.79 & 0.85 & 539 & 710 & 880 & 0.82 & 0.81 & 0.78 \\
\hline Tarnobrzeskie & 360 & 506 & 685 & 0.73 & 0.71 & 0.73 & 487 & 638 & 805 & 0.74 & 0.73 & 0.71 \\
\hline Tarnowskie & 380 & 503 & 640 & 0.77 & 0.71 & 0.68 & 443 & 610 & 774 & 0.67 & 0.70 & 0.68 \\
\hline
\end{tabular}


Table 3 Persistent gaps in mean monthly wages across regions (Continued)

\begin{tabular}{lrrrrrrrrrrrr}
\hline Torunskie & 385 & 527 & 712 & 0.78 & 0.74 & 0.76 & 452 & 604 & 758 & 0.69 & 0.69 & 0.67 \\
Walbrzyskie & 397 & 498 & 614 & 0.80 & 0.70 & 0.66 & 481 & 616 & 778 & 0.73 & 0.70 & 0.69 \\
Warszawskie & 496 & 713 & 934 & 1.00 & 1.00 & 1.00 & 657 & 877 & 1131 & 1.00 & 1.00 & 1.00 \\
Wloclawskie & 356 & 481 & 583 & 0.72 & 0.67 & 0.62 & 444 & 586 & 749 & 0.68 & 0.67 & 0.66 \\
Wroclawskie & 398 & 593 & 758 & 0.80 & 0.83 & 0.81 & 501 & 659 & 844 & 0.76 & 0.75 & 0.75 \\
Zamojskie & 325 & 429 & 610 & 0.66 & 0.60 & 0.65 & 425 & 567 & 718 & 0.65 & 0.65 & 0.64 \\
Zielonogorskie & 385 & 494 & 648 & 0.78 & 0.69 & 0.69 & 450 & 597 & 742 & 0.68 & 0.68 & 0.66 \\
Mean & $\mathbf{3 8 2}$ & $\mathbf{5 2 4}$ & $\mathbf{6 9 6}$ & $\mathbf{0 . 7 7}$ & $\mathbf{0 . 7 3}$ & $\mathbf{0 . 7 4}$ & $\mathbf{4 7 9}$ & $\mathbf{6 2 9}$ & $\mathbf{7 9 7}$ & $\mathbf{0 . 7 3}$ & $\mathbf{0 . 7 2}$ & $\mathbf{0 . 7 1}$ \\
SD & $\mathbf{4 4}$ & $\mathbf{6 0}$ & $\mathbf{7 3}$ & $\mathbf{0 . 0 8 8}$ & $\mathbf{0 . 0 8 4}$ & $\mathbf{0 . 0 7 8}$ & $\mathbf{5 4}$ & $\mathbf{7 8}$ & $\mathbf{8 7}$ & $\mathbf{0 . 0 8 1}$ & $\mathbf{0 . 0 8 9}$ & $\mathbf{0 . 0 7 7}$ \\
Min & $\mathbf{2 9 6}$ & $\mathbf{4 2 1}$ & $\mathbf{5 8 2}$ & $\mathbf{0 . 6 0}$ & $\mathbf{0 . 5 9}$ & $\mathbf{0 . 6 2}$ & $\mathbf{4 2 5}$ & $\mathbf{3 7 9}$ & $\mathbf{6 9 9}$ & $\mathbf{0 . 6 5}$ & $\mathbf{0 . 4 3}$ & $\mathbf{0 . 6 2}$ \\
Max & $\mathbf{5 0 4}$ & $\mathbf{7 1 3}$ & $\mathbf{9 3 4}$ & $\mathbf{1 . 0 1}$ & $\mathbf{1 . 0 0}$ & $\mathbf{1 . 0 0}$ & $\mathbf{6 6 4}$ & $\mathbf{8 7 7}$ & $\mathbf{1 1 3 1}$ & $\mathbf{1 . 0 1}$ & $\mathbf{1 . 0 0}$ & $\mathbf{1 . 0 0}$ \\
\hline
\end{tabular}

equation (4), $w^{*}(t)$, and optimal layoff rate from non-restructured sector, $d N_{N R}^{*}(t) / d t$, from equation (1).

The above analysis gives a good economic foundation for why wage levels in period (t) respond to period ( $\mathrm{t}$ ) (excessive) layoffs and hiring rates (as a percentage of the labor force, normalized to one). We re-write equation (4) as follows,

$$
\ln w_{j t}=\ln (b+\rho)+2 \ln c_{j}+\beta_{1} \ln \left(\frac{b N_{R}}{d t}\right)_{j t}-\beta_{2} \ln U_{j t}+\varepsilon_{j t}
$$

Pay in region $j$ is negatively related to the unemployment rate (excessive annual layoffs effective in job search) and positively related to the hiring rate in region $j$ in period $t$, among other country (benefit system) and regional $j$ (compensating differentials) specific determinants. At this level of aggregation one should have a set of proposed instruments and controls for unobserved regional heterogeneity. The authors' strategy is to model the, on average, response of individual wages to the local short-term unemployment (excessive layoffs) rate and the local annual hiring rate, on average, controlling for individual characteristics and selection to employment. The objective is to see whether the pace of labor reallocation can account for differences in mean regional wages.

An empirical relationship between the wage level and local unemployment and hiring rates is not new but the theoretical interpretation of these correlations is of great

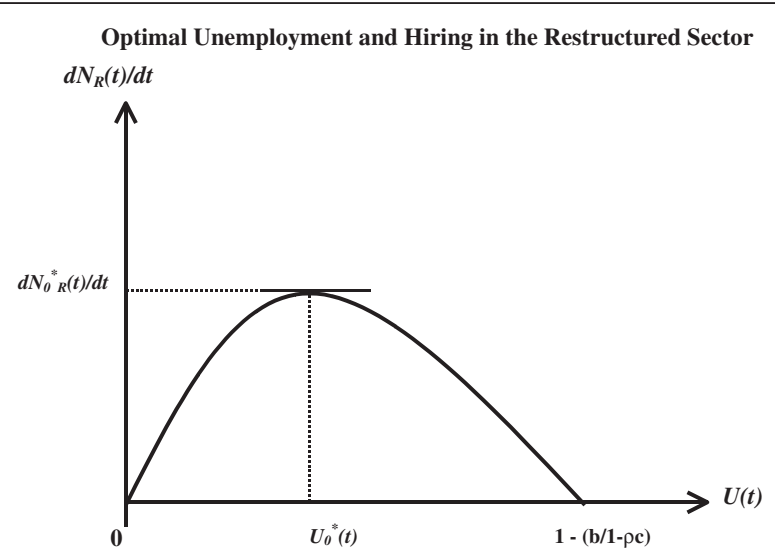

Figure 1 Optimal unemployment and hiring in the restructured sector. 
interest ${ }^{9}$. In general equilibrium models where the conventional labor supply curve is replaced with a wage setting curve, as in the Aghion and Blanchard (1994), a negative relationship between pay and the unemployment rate is clearly predicted ${ }^{10}$. Motivated by theories of imperfectly competitive theories of wage setting, many authors provide evidence that regional pay and unemployment are negatively correlated; Blackaby and Manning 1987, 1990a, 1990b, 1990c using British Data, Freeman (1988) using American data, Card (1990) using Canadian data and Janssens and Konings (1999) using Belgian data ${ }^{11}$.

Blanchflower and Oswald (1994) document a negative empirical relationship between local unemployment and pay determination, which they term a "Wage Curve". A typical wage curve is described by the following specification;

$$
\ln W_{i t}=\beta_{0}-0.1 \ln U_{j t}+\beta_{2} X_{i t}+\beta_{2} D_{j}+\beta_{3} D_{t}+\varepsilon_{i t}
$$

The natural logarithm of individual $i$ in period $t$ hourly/monthly/yearly earnings, $W_{i t}$, is explained by the natural logarithm of region $j$ unemployment rate, $U_{j t}$, a vector of workplace and human capital characteristics, $X_{i b}$ (age, education, work experience and employment sector), regional and time dummies, $D_{j}$, and $D_{b}$, respectively. Regression results on samples across 12 countries suggest that the unemployment elasticity of pay approximates -0.1: a hypothetical doubling of unemployment is associated with a drop in pay of 10\%. Using the International Social Survey Programme series from 1991-1997 for nine countries, Blanchflower (2001) estimates wage curves for many CEE countries, including Poland. The elasticity of pay with respect to unemployment is estimated to be -0.13 using data on 4,747 individuals across 8 Polish regions. While magnitudes in the unemployment elasticity of pay vary across countries it seems that transition countries display more elastic responses ${ }^{12}$.

While the authors estimate the relationship between the level of pay and local shortterm unemployment for males across all Polish regions using LFS data, the real strength of this research is that it is done in the context of imperfectly competitive wage setting in a labor market in transition, the Aghion and Blanchard (1994) model. The short-term unemployment rate is used to capture excessive layoffs during an interval of a year, that are active in job search. This excludes the long term unemployed (LTU). The idea is to include job searchers in unemployment that reduce wage pressure. The aim is to capture the impact of excessive annual layoffs on wage setting in the context of the Aghion and Blanchard (1994) model ${ }^{13}$.

The other side of labor reallocation in the Aghion and Blanchard (1994) model is that pay should be positively related to the annual hiring rate. Belzil (2000) was the first to examine the sensitivity of individual pay, to the job creation rate while controlling for the business cycle with the unemployment rate in the context of an individual country specific study. Structural change in employment, not captured by business cycle indicators, can be an important "omitted variable" in wage equations.

\section{Section III: Empirical evidence}

The Polish LFS is a quarterly household survey. This paper uses three data waves of the survey, corresponding to the November 1994, 1995 and 1996 waves. The survey includes individuals older than 15 years and there is no upper age limit. However it does omit individuals living in military barracks and dormitories, and any household 
members residing abroad. The Polish LFS is similar to the usual western survey. It contains more than 50 questions and allows one to distinguish between the employed, the unemployed and those not in the labor force according to ILO/OECD definitions. Females are intentionally excluded in this study as they have more complex participation considerations than their male counterparts.

The total number of observations on males is 75,000 over 1994, 1995, and 1996. For each observation a record of age, type of completed education, regional location (voivodship), sector attachment in the reference week (reporting of sector attachment in non-employment is poor), tenure of current job, years of work experience, marriage status, and earnings are used which corresponds to their net earnings in the previous month from a full time job measured in thousands of polish zloty ${ }^{14}$. The analysis is based on real earnings using the national consumer price index ${ }^{15}$.

Regional short-term unemployment rates (UR) and regional local annual hiring rates (HR) are constructed from the LFS data. Normally, previous literature uses local unemployment rates, which includes the long-term unemployed. The local short-term unemployed are those that became unemployed during the year and are actively searching for work as a percentage of the labor force. This study uses the regional local short-term unemployment rate. This is a proxy for the annual (excessive) layoff rate that drives the space of labor reallocation in the theoretical model. Regional hiring rates are constructed by counting all individuals that have current job tenure less than a year as a percentage of the labor force. These variables are summarized in Table 2. A wage equation is described by the following specification,

$$
\ln W_{i t}=\beta_{0}+\beta_{1} \ln S T U R_{j t}+\beta_{2} \ln H R_{j t}+\beta_{3} X_{i t}+\beta_{4} D_{j}+\beta_{5} D_{t}+\varepsilon_{i t}
$$

The natural logarithm of individual $i$ previous months real net earnings from a full time job, ${ }^{16} W_{i b}$ in period $t$ is explained by the natural logarithm of the regional short- term unemployment rate, $S T U R_{j b}$ and the regional annual hiring rate, $H R_{j t}$. The paper controls for non-linearity's in age, work experience, education by category and sector dummies, $\mathrm{X}_{i t}$, regional and time dummies, $D_{j}$, and $D_{t}$, respectively.

In Table 4 descriptive statistics are outlined for individual characteristics summarized for those in the state of full time employment and non-employment. It is clear that a slight majority have switched out of their planning job during transition. This varies greatly across regions. The growth of the non-employment pool has been a big part of transition. It is seen that older, less educated males with long spells in planning have increasingly found themselves in non-employment during transition. The pace of this also differs across regions, reflecting the speed of structural change in employment.

Table 5 reports results for an employed sample of males assuming random selection 17. In column I the responsiveness of individual wages to the local short-term unemployment rate and local annual hiring rate is reported with only time dummies used as additional variables. In columns II and III it is seen that the estimates are robust to adding sector and region dummies.

In column IV controls are included for education ${ }^{18}$. Years of schooling are not a good control variable for education. Following the literature, the nature of education under a communist regime turns out to be important. Flanagan (1994) using pre and post-transition data for the Czech Republic, includes education in the form of categorical variables, and finds a decrease in the rate of return to vocational education from 
Table 4 Descriptive statistics

\begin{tabular}{|c|c|c|c|c|c|c|c|c|}
\hline \multirow[t]{2}{*}{ Employment } & \multirow[t]{2}{*}{ Obs. } & \multirow[t]{2}{*}{ Mean } & \multirow[t]{2}{*}{ Std. Dev. } & \multicolumn{5}{|c|}{ Percentiles } \\
\hline & & & & $10 \%$ & $25 \%$ & $50 \%$ & $75 \%$ & $90 \%$ \\
\hline Net Monthly Wage & 26404 & 569.2 & 329.1 & 280 & 360.8 & 494.8 & 670.3 & 927.8 \\
\hline Age & 26404 & 37 & 10.2 & 24 & 29 & 37 & 45 & 51 \\
\hline Work Experience & 26404 & 11 & 10.8 & 1 & 3 & 7 & 17 & 26 \\
\hline Married & 26404 & .8 & .4 & & & & & \\
\hline Education & 26404 & & & & & & & \\
\hline No Primary & .10 & & & & & & & \\
\hline Technical Training & 14.13 & & & & & & & \\
\hline Primary Education & 46.71 & & & & & & & \\
\hline Technical High School & 2.80 & & & & & & & \\
\hline High School & 23.64 & & & & & & & \\
\hline Technical College & 1.61 & & & & & & & \\
\hline University & 11.02 & & & & & & & \\
\hline \multirow[t]{2}{*}{ Non- Employment } & Obs. & Mean & Std. Dev. & \multicolumn{5}{|c|}{ Percentiles } \\
\hline & & & & $10 \%$ & $25 \%$ & $50 \%$ & $75 \%$ & $90 \%$ \\
\hline Age & 48800 & 44 & 20.2 & 17 & 23 & 44 & 61 & 71 \\
\hline Work Experience & 38434 & 26 & 17.3 & 3 & 10 & 29 & 43 & 50 \\
\hline Married & 48800 & .6 & .48 & & & & & \\
\hline Education & 48800 & & & & & & & \\
\hline No Primary & 5.20 & & & & & & & \\
\hline Technical Training & 43.58 & & & & & & & \\
\hline Primary Education & 27.69 & & & & & & & \\
\hline Technical High School & 3.96 & & & & & & & \\
\hline High School & 14.21 & & & & & & & \\
\hline Technical College & 0.68 & & & & & & & \\
\hline University & 4.66 & & & & & & & \\
\hline
\end{tabular}

0.11 to 0.07 and an increase in the rate of return to university education from 0.31 to 0.39. Chase (1997) using similar data for the Czech Republic finds that the returns to technical education/training greatly diminished while returns to academic education experienced a large increase during transition. We see from column IV that returns to education are higher for those that have more general or academic education compared to those with narrow or technical training at each stage of schooling. This emphasizes the need for categorical variables as controls for education.

In columns $\mathrm{V}$ and VI of Table 5 controls are included for age, with and without sector dummies. Finally, in columns VII and VIII, the authors add controls for current job tenure. Much of the work experience gained under communism by workers may not be rewarded so well in a market economy. Younger age groups have less work experience but any work experience accumulated, particularly during transition, may be highly rewarded in the market economy. This allows for such a non-linearity in age and for a flat experience and earning profile as documented for many other CEE countries ${ }^{19}$. The estimated short-term unemployment elasticity of pay, -0.29 , and annual hiring rate elasticity of pay, 0.75 , remain even after including a rich set of individual controls. 
Table 5 Wage regressions across polish individuals

\begin{tabular}{|c|c|c|c|c|c|c|c|c|}
\hline & 1 & II & III & IV & v & VI & VII & VIII \\
\hline $\mathrm{R}^{2}$ & .08 & .11 & .19 & .30 & .33 & .26 & .40 & .27 \\
\hline Constant & $6.1(23.3)^{*}$ & $6.5(12.1)^{*}$ & $6.3(11.6)^{*}$ & $6.2(9.6)^{*}$ & $5.1(8.3)^{*}$ & $4.9(8.3)^{*}$ & $5.3(8.6)^{*}$ & $5.3(8.4)^{*}$ \\
\hline In STU Rate & $-.29(2.4)^{*}$ & $-.29(2.4)^{*}$ & $-.28(2.3)^{*}$ & $-.29(2.4)^{*}$ & $-.29(2.5)^{*}$ & $-.29(2.4)^{*}$ & $-.29(2.4)^{*}$ & $-.29(2.4)^{*}$ \\
\hline In Hiring Rate & $.71(4.2)^{*}$ & $.71(4.2)^{*}$ & $.72(4.2)^{*}$ & $.73(4.2)^{*}$ & $.74(4.3)^{*}$ & $.74(4.4)^{*}$ & $.75(4.3)^{*}$ & $.76(4.5)^{*}$ \\
\hline Age & & & & & $.07(5.8)^{*}$ & $.09(4.3)^{*}$ & $.05(4.4)^{*}$ & $.06(3.8)^{*}$ \\
\hline $\mathrm{Age}^{2}$ & & & & & $-.001(4.8)^{*}$ & $-.002(3.7)^{*}$ & $-.001(3.4)^{*}$ & $-.001(3.1)^{*}$ \\
\hline $\mathrm{Age}^{3}$ & & & & & $\begin{array}{l}.000001 \\
(4.1)^{*}\end{array}$ & $\begin{array}{c}.000001 \\
(4.1)^{*}\end{array}$ & $\begin{array}{l}.000001 \\
(2.5)^{*}\end{array}$ & $\begin{array}{c}.000001 \\
(2.5)^{*}\end{array}$ \\
\hline Work Experience & & & & & & & $.02(7.2)^{*}$ & $.02(6.16)^{*}$ \\
\hline Work Experience ${ }^{2}$ & & & & & & & $-.001(5.8)^{*}$ & $-.001(6.8)^{*}$ \\
\hline Work Experience ${ }^{3}$ & & & & & & & $\begin{array}{l}.00002 \\
(5.2)^{*}\end{array}$ & $\begin{array}{l}.00002 \\
(6.7)^{*}\end{array}$ \\
\hline Technical Training & & & & $.03(0.5)$ & $.03(0.2)$ & $.01(0.2)$ & $.01(0.2)$ & $.01(0.9)$ \\
\hline Primary Education & & & & $.06(0.8)$ & $.10(1.3)$ & $.14(1.7)$ & $.10(1.3)$ & $.13(1.8)$ \\
\hline $\begin{array}{l}\text { Technical High } \\
\text { School }\end{array}$ & & & & $.18(2.4)^{*}$ & $.20(2.7)^{*}$ & $.24(3.1)^{*}$ & $.20(2.6)^{*}$ & $.23(3.1)^{*}$ \\
\hline High School & & & & $.21(2.8)^{*}$ & $.23(3.12)^{*}$ & $.27(3.52)^{*}$ & $.23(3.0)^{*}$ & $.26(3.4)^{*}$ \\
\hline Technical College & & & & $.24(2.9)^{*}$ & $.27(3.4)^{*}$ & $.24(2.8)^{*}$ & $.27(3.3)^{*}$ & $.24(2.7)^{*}$ \\
\hline University & & & & $.60(8.0)^{*}$ & $.61(8.1)^{*}$ & $.58(7.4)^{*}$ & $.61(7.9)^{*}$ & $.58(7.4)^{*}$ \\
\hline Sector Dummies & No & No & Yes & Yes & Yes & No & Yes & No \\
\hline Regional Dummies & No & Yes & Yes & Yes & Yes & Yes & Yes & Yes \\
\hline Year Dummies & Yes & Yes & Yes & Yes & Yes & Yes & Yes & Yes \\
\hline Observations & 26,404 & 26,404 & 26,404 & 26,404 & 26,404 & 26,404 & 26,404 & 26,404 \\
\hline
\end{tabular}

T-statistics in parenthesis, Assuming Random Selection 1994-1996.

* indicates significance at the $5 \%$ level.

* Robust Standard Errors, Number of clusters (regions) $=49$.

How much of the mean earnings gap across regions is explained by local annual rates of (excessive) layoffs and hiring? Warsaw pays 31 per cent more, on average, than the mean pay across all other regions during the period 1994-1996. In Table 6, using the estimated short-term unemployment elasticity of pay and annual hiring rate elasticity of pay the authors predict how much of this gap in average earnings, relative to Warsaw, across regions is explained by log differences regional annual (excessive) layoffs and hiring rates. While the effect varies from region to region, the pace of local labor demand dynamics, on average, explains most of the differential in mean pay across regions. While individual characteristics can determine participation rates and where one is on the wage distribution within regions, the pace of local annual (excessive) layoffs and hiring rates are shown to dictate the mean wage disparities across regions.

\section{Conclusion}

The Polish labor market in early transition was inhibited by the lack of inter-regional worker and job flows and intra-region differences in the pace of employment restructuring. Yet, these legacies of planning have allowed this research to study the importance of regional labor demand dynamics on earnings, as outlined in Aghion and Blanchard (1994), in an environment far less complex than that observed in mature market economies. While individual characteristics are clearly important for determining labor force participation 
Table 6 Decomposition of wage gaps (averaged over 1994-1996) relative to Warsaw: estimated contribution of relative InSTU rates and annual inhiring rates

\begin{tabular}{|c|c|c|c|c|}
\hline Region & $\begin{array}{c}\text { \% Wage Gap } \\
\text { Relative to Warsaw }\end{array}$ & $\begin{array}{l}\text { \% Estimated due } \\
\text { Difference in InSTU }\end{array}$ & $\begin{array}{c}\text { \% Estimated due } \\
\text { Difference in InHIRING }\end{array}$ & Residual \\
\hline Bialostockie & 43.2 & 4.7 & 33.6 & 4.8 \\
\hline Bialskopodlaskie & 32.4 & 8.8 & 25.1 & -1.5 \\
\hline Bielskie & 22.8 & 4.7 & 6.7 & 11.3 \\
\hline Bydgoskie & 23.0 & 21.8 & 10.9 & -9.7 \\
\hline Chelmskie & 31.9 & 8.8 & 32.5 & -9.4 \\
\hline Ciechanowskie & 32.6 & 14.6 & 8.4 & 9.6 \\
\hline Czestochowskie & 34.3 & 15.0 & 19.2 & 0.1 \\
\hline Elblaskie & 32.1 & 17.6 & -1.0 & 15.6 \\
\hline Gdanskie & 10.6 & 9.7 & 0.8 & 0.1 \\
\hline Gorzowskie & 27.8 & 27.8 & -3.8 & 3.9 \\
\hline Jeleniogorskie & 27.0 & 27.4 & -4.4 & 4.0 \\
\hline Kaliskie & 39.3 & 11.9 & 21.9 & 5.5 \\
\hline Katowickie & 4.0 & -3.1 & 25.7 & -18.7 \\
\hline Kieleekie & 37.0 & 11.2 & 29.2 & -3.4 \\
\hline Koninskie & 21.1 & 18.4 & 34.7 & -32.0 \\
\hline Koszalinskie & 34.6 & 33.4 & -9.7 & 10.9 \\
\hline Krakowskie & 22.3 & 2.2 & 19.6 & 0.5 \\
\hline Krosnienskie & 43.1 & 12.0 & 20.1 & 11.0 \\
\hline Legnickie & 20.6 & 16.9 & 26.7 & -23.0 \\
\hline Leszezynskie & 41.7 & 12.9 & 12.3 & 16.4 \\
\hline Lodzkie & 22.7 & 7.9 & 28.2 & -13.4 \\
\hline Lomzynskie & 37.8 & 7.6 & 28.5 & 1.7 \\
\hline Lubelskie & 29.2 & 22.0 & 9.7 & -2.5 \\
\hline Nowosadeckie & 44.7 & 12.1 & 22.5 & 10.1 \\
\hline Olsztynskie & 33.1 & 25.9 & 4.6 & 2.6 \\
\hline Opolskie & 19.2 & 7.4 & 13.8 & -2.1 \\
\hline Ostroleckie & 34.3 & 20.2 & 14.7 & -0.5 \\
\hline Pilskie & 32.1 & 21.5 & 4.2 & 6.3 \\
\hline Piotrkowskie & 27.7 & 16.5 & 23.8 & -12.6 \\
\hline Plockie & 17.7 & 13.0 & 20.3 & -15.6 \\
\hline Poznanskie & 27.6 & 4.8 & 15.7 & 7.1 \\
\hline Premyskie & 45.9 & 12.6 & 47.1 & -13.8 \\
\hline Radomskie & 36.2 & 14.8 & 29.3 & -7.8 \\
\hline Rzeszowskie & 39.4 & 11.0 & 13.8 & 14.6 \\
\hline Siedleckie & 31.0 & 7.8 & 19.4 & 3.8 \\
\hline Sieradzkie & 39.5 & 16.2 & 26.2 & -2.9 \\
\hline Skierniewickie & 35.1 & 5.1 & 18.5 & 11.5 \\
\hline Slupskie & 34.3 & 38.3 & 0.4 & -4.3 \\
\hline Suwalskie & 28.0 & 32.3 & 19.4 & -23.7 \\
\hline Szezecinskie & 17.4 & 17.6 & 0.1 & -0.4 \\
\hline Tarnobrzeskie & 33.6 & 8.8 & 38.4 & -13.6 \\
\hline Tarnowskie & 36.3 & 7.2 & 15.1 & 14.0 \\
\hline Torunskie & 28.8 & 20.8 & 13.2 & -5.3 \\
\hline
\end{tabular}


Table 6 Decomposition of wage gaps (averaged over 1994-1996) relative to Warsaw: estimated contribution of relative InSTU rates and annual inhiring rates (Continued)

\begin{tabular}{lcccc}
\hline Walbrzyskie & 37.1 & 25.2 & 16.7 & -4.7 \\
Warszawskie & 0.0 & 0.0 & 0.0 & 0.0 \\
Wloclawskie & 40.7 & 25.0 & 27.6 & -11.9 \\
Wroclawskie & 20.4 & 11.1 & -2.4 & 11.8 \\
Zamojskie & 43.0 & 22.2 & 26.3 & 11.0 \\
Zielonogorskie & 33.9 & $\mathbf{1 4 . 6}$ & 8.3 & 3.4 \\
Average & $\mathbf{3 0 . 4}$ & $\mathbf{8 . 8 3}$ & $\mathbf{1 6 . 6}$ & $\mathbf{- 0 . 8}$ \\
SD & $\mathbf{9 . 8 8}$ & & $\mathbf{1 2 . 4 1}$ & $\mathbf{1 1 . 0 2}$ \\
\hline
\end{tabular}

rates and where one is on the wage distribution within regions, differences in mean wage across regions are clearly dictated by the pace of regional employment restructuring. In other words, differences in expected pay across regions are explained more by the pace of structural change in labor demand and less by labor supply considerations. It is found that structural change in employment has a first order effect on wages in a labor market in early transition. The importance of an unemployment benefits and good infrastructure for the private sector cannot be underestimated for an efficient worker reallocation path.

\section{Endnotes}

${ }^{1}$ Worker reallocation referred to the movement of workers from the non-privatized to the privatized sector. Since many privatized enterprises resisted restructuring, while some state owned undertook restructuring this dichotomy is empirically problematic. This has clearly been shown in the literature on firm performance and ownership; see Walsh and Whelan (2001). Hence we work in terms of a non-restructured traditional enterprises and restructured (traditional and de novo) enterprises dichotomy.

${ }^{2}$ Exogenous (government imposed) restructuring can be replaced with a model of endogenous (insider controlled) restructuring. To opt for restructuring, the expected income from restructuring must compensate workers for the risk of becoming unemployed and for their forgone income stream from the non-restructured state. Workers require a wage premium for risk exposure during restructuring. With endogenous restructuring, annual layoff and hiring rates can fuel wage pressure over an above that created by exogenous government control of restructuring.

${ }^{3}$ The assertion is that the need for structural change in employment is first order in a labor market in transition. Traditional enterprises need to downsize and new enterprises are needed to create outside options for job searchers. Pay is more about labor demand dynamics and less about inherited human capital and participation considerations during the transition period.

${ }^{4}$ We examine wage behavior in an in-depth study of Poland's regional experience. A country study can miss important heterogeneity in regional labor demand dynamics. Within a regional study of Poland over a relatively short time period, the data, the culture and the macroeconomic institutions can be assumed to be similar across regions, while the pace of structural change in labor demand varied greatly.

${ }^{5}$ Boeri and Scarpetta (1996) document idiosyncratic initial conditions within regions as the main reason for different speeds of regional employment restructuring during transition. 
${ }^{6}$ One feature of the LFS data is that earnings are only reported for full time hired employees. There is missing data on the self-employed and part-time workers.

${ }^{7}$ This model of exogenous (government controlled) restructuring can be replaced with a model of endogenous restructuring. During the reforms in 1990, majority insider privatization ensured workers took control of firms. The following condition had to be satisfied before workers would vote for restructuring, $\mathrm{rV}_{\mathrm{N}} \leq \lambda r V_{R}+(1-\lambda) r V_{U}$. The expected income stream for a worker, ex-post restructuring, must be at least as great as the current income stream in the non-restructured state, $r V_{N}$. A worker is given a probability $\lambda$ of remaining in the restructured firm, earning an income stream of $\mathrm{rV}_{\mathrm{R}}$, and a probability (1- $\lambda)$ of becoming unemployed with an expected income stream of $\mathrm{rV}_{\mathrm{U}}$. The expected income stream after restructuring must compensate the worker for the risk of becoming unemployed and for the forgone expected income stream from the non-restructured state. One can write down the expected income stream in the event of a flow into unemployment, $\mathrm{rV}_{\mathrm{U}}$, and the expected income stream for a worker in the non-restructured state, $\mathrm{rV}_{\mathrm{N}}$. The minimum ex-post income stream, $r V_{R}$, necessary to induce an ex-ante vote for restructuring can be expressed as $r V_{R}=r V_{U}+c / \lambda$. Workers require a premium for exposing themselves to the risk of becoming unemployed during the restructuring process, as $0<\lambda<1$. With endogenous restructuring, annual layoff and hiring rates in restructured enterprises, can fuel wage pressure over an above that created by exogenous government control of restructuring where $\lambda=1$.

${ }^{8}$ This approach imposes exogenous mark-ups in the restructured product and labor market. The explicit modeling of imperfections in product and labor markets can be found in Konings and Walsh (1994, 2000) and Bughin (1996).

${ }^{9}$ From the beginning of the 1970s, based on Adam Smith's theory of "compensating differentials" and a long-run zero migration equilibrium, Harris and Todaro (1970) argued that regions with high unemployment should also experience high wage levels. Hall (1970, 1972), Reza (1978), Adams (1985) and Marston (1985) find such a positive relationship.

10 The macroeconomic models of Layard et al. (1991) and the microeconomic efficiency wage model of Shapiro and Stiglitz (1984) are good examples of modeling negatively related wage and unemployment outcomes with conventional labor demand equations and imperfectly competitive wage setting behavior

${ }^{11}$ This correlation refers to levels of unemployment and wages and not changes in these variables found in a conventional regional Phillips curves.

${ }^{12}$ As summarized by Blanchflower (2001), prior to his work only a small literature estimated wage curves using individual micro data for Eastern Europe [for example Kertese and Kallo (1997) for Hungary and Pannenberg and Schwarze (1998) for East Germany].

${ }^{13}$ Why these magnitudes in the unemployment elasticity of pay vary across countries, by gender or by the measure of unemployment, can be debated, but will depend on the model of imperfectly competitive wage setting one has in mind. There are many ways to replace the conventional labor supply curve.

${ }^{14}$ Some may like to see individual controls for the ownership structure of the firm. In addition, one could have constructed excessive layoff rates for workers coming from state firms and hiring rates for workers flowing into privatized firms. Since many privatized enterprises resisted restructuring, while some state owned undertook restructuring this 
dichotomy is empirically very problematic. This has clearly been shown in the literature on firm performance and ownership; see Walsh and Whelan (2001). Hence we work in terms of (excessive) layoffs and hiring rates in general expecting that they capture ongoing restructuring of traditional enterprises and expansion of de novo enterprises.

${ }^{15}$ A potential criticism of our work is that to measure real wages in different regions one should have regional consumer price data. However, we do have regional dummies in our regression equations to control for such an error.

${ }^{16}$ Admittedly, part time workers and self-employed are excluded. On the plus side, males in full time mainstream jobs are likely report earnings accurately.

${ }^{17}$ The results are very similar when one employs a two step Heckman procedure.

${ }^{18}$ Normally in mature market economies we would expect investment in human capital to target high wage occupations. This selection bias is not a strong feature of this data as most human capital and occupation structures were an outcome of the planning era. We do not worry about instruments for education.

${ }^{19}$ Flanagan (1994) finds that the return to work experience gained under planning declined during the first few years of transition in the Czech Republic. Chase (1997) using micro-data for the Czech Republic and Slovakia also finds that returns to work experience fell during transition as young workers were favored in jobs created during transition. Krueger and Pischke (1995) and Bird et al. (1994) for East Germany, Halpern and Korosi (1997) for Hungary and Lehmann and Wadsworth (2000) for Russia and Poland document very flat experience earning profiles. Return to experience gained under planning clearly fell during transition.

\section{Appendix}

Annex I: 2-digit sector categories

Agriculture, fishing and forestry

- Forestry, logging and related service activities.

- Agriculture, hunting and related service activities.

- Fishing, operation of fish hacteries and fish farms.

Mining

- Mining \& Extraction of coal and lignite, crude petroleum and natural gas, uranium \& thorium ores, metal ores.

- Other quarrying.

\section{Manufacturing}

- Food products \& beverages

- Tobacco products

- Textiles, wearing apparel, tanning and dressing of leather, manufacture of luggage, handbags, saddlery, harness and footwear.

- Wood, (and of products of wood and cork except furniture), pulp, paper and paper products.

- Publishing, printing and reproduction of recorded media. 
- Coke, refined petroleum products and nuclear fuel.

- Chemicals and chemical products.

- Rubber and plastic products.

- Other non-metallic mineral products.

- Basic metals.

- Machinery, \& equipment, office machinery and computers, electrical machinery, manufacture of medical, precision \& optical instruments, watches and clocks.

- Manufacture of fabricated metal products.

- Manufacture of motor vechicles \& other transport equipment.

- Other manufacturing: including manufacture of furniture, and recycling.

Electricity, gas and water supply

- Electricity, gas, steam and hot water supply. Collection purification and distribution of water

- construction

- Construction

Wholesale \& retail trade

- Retail \& wholesale trade, repair of household and personal goods.

Hotels \& restaurants

- Hotels and restaurants.

Transport storage and communication

- Land transport, water transport, air transport, cargo handling and storage, other supporting transport activities, activities of transport agencies.

Financial intermediation.

- Financial intermediation, insurance and pension funding, except compulsory social security, activities auxiliary to financial intermediation.

- Real estate activities, renting of machinery and equipment.

Public administration and defense

- Public administration and defense.

\section{Education}

- Education.

Health \& social work 


\section{- Health and social work.}

\section{Other services}

- Other Community, social and personal service activities Sewage \& refuse disposal, sanitation, recreational, cultural and sporting activities, other service activities, Private households with employed persons.

\section{- Private Households With Employed Persons.}

\section{- Extra-territorial organisations and bodies.}

\section{Competing interest}

"The IZA Journal of Labor \& Development is committed to the IZA Guiding Principles of Research Integrity. The authors declare that they have observed these principles".

\section{Acknowledgements}

This paper was presented to LICOS in Leuven, CEPR/WDI in Moscow and IZA in Bonn. We thank all participants for their comments. We are also grateful to an anonymous referee, Jozef Konings, Hartmut Lehmann, Jan Svejnar, Jonathan Wadsworth, Ciara Whelan and Frank Walsh for valuable comments. Fiona Duffy was funded by a Government of Ireland Research Scholarship during the course of this research.

Responsible editor: Hartmut Lehmann.

\section{Author details}

'Department of Management Studies, IT Carlow, Carlow, Ireland. ${ }^{2}$ School of Politics and International Relations, UCD, Dublin, Ireland.

Received: 1 November 2012 Accepted: 19 December 2012

Published: 27 December 2012

\section{References}

Adams JD (1985) Permanent differences in unemployment and permanent wage differentials. Q J Econ 100:29-56 Aghion P, Blanchard O (1994) "On the speed of transition in central Europe". NBER Macroeconomic Annual 9:283-320 Belzil C (2000) Job creation and job destruction, worker reallocation, and wages. J Labor Econ 18(2):183-203 Bird E, Schwarze J, Wagner G (1994) Wage effects of the move towards free markets in East Germany. Ind Labor Relat Rev 47(3):390-400

Blackaby DH, Manning DN (1987) "Regional earnings revisited". Manchester School 55:158-183

Blackaby DH, Manning DN (1990a) "Earnings, unemployment and the regional employment structure in Britain". Regional Studies 24:529-535

Blackaby DH, Manning DN (1990b) "The north-south divide: earnings, unemployment and the cost of living differences in Great Britain". Pap Reg Sci Assoc 69:43-55

Blackaby DH, Manning DN (1990c) "The north-south divide: questions of existence and stability". Economic J 100:510-527

Blanchflower DG, Oswald AJ (1994) The Wage Curve. MIT Press, Cambridge

Blanchflower DG (2001) Unemployment, Well-being and Wage Curves in Eastern and Central Europe. Mimeograph Department of Economics, Dartmouth College

Boeri T, Scarpetta S (1996) Regional mismatch and the transition to a market economy. Labour Economics 3:233-254

Bughin J (1996) "Trade unions and firms' product market power". J Ind Economics 3:289-307, Vol. XLIV

Card D (1990) "Unexpected inflation, real wages and employment determination in union contracts". Am Econ Rev 80:669-688

Chase R (1997) "Markets for Communist Human Capital: Returns to Education and Experience in Post-Communist Czech Republic and Slovakia", Working Paper no.81. WDI, University of Michigan Business School Michigan: University of Michigan

Deichmann U, Henderson V (2000) "Urban and Regional Dynamics in Poland". World Bank Working PaperInfrastructure, Telecoms, Power and Water, Washington No. 2457

Faggio G, Konings J (2003) "Gross Job Flows and Firm Growth in Transition Countries: Evidence using Firm Level Data on Five Countries" forthcoming in Economic Systems (27):129-154

Flanagan R (1994) Were Communists Good Human Capitalists? The Case of the Czech Republic. Mimeograph Stanford University

Freeman RB (1988) "Evaluating the european view that the united states has no unemployment problem". Am Econ Rev Pap Proc 78:294-299

Hall RE (1972) "Turnover in the labor force". Brookings Pap Econ Act 3:709-756

Hall RE (1970) "Why is the unemployment rate so high at full employment". Brookings Papers on Economic Activity 3:369-402

Halpern L, Korosi G (1995) "Labor Market Characteristics and Profitability (Econometric Analysis of Hungarian Firms), 1986-1995", Working Paper No. 41. WDI, University of Michigan Business School, Working Paper No. 41

Harris JR, Todaro MP (1970) "Migration, unemployment and development: a two-sector analysis". Am Econ Rev 60:126-142

Janssens S, Konings J (1999) One More Wage Curve: The Case of Belgium. Economic Letters (60):223-227

Kertese G, Kallo J (1997) "The birth of the "Wage Curve" in Hungary, 1989-95". William Daviidson Institute Working

Paper \#104, University of Michigan Business School Michigan: University of Michigan 
Konings J, Walsh P (2000) " The impact of product market competition on employment determination in unionized and non-unionized firms: firm level evidence for the UK ". Rev Ind Organ 4:385-394

Konings J, Walsh P (1994) "Evidence of efficiency wage payments in U.K. firm level panel data". Econ J 104:542-555

Krueger A, Pischke JS (1995) A Comparative Analysis of East and West German Labor Markets: Before and After

Unification. In: Freeman RB, Katz LK (eds) Differences and Changes in Wage Structures. University of Chicago Press, Chicago, IL

Layard R, Nickell S, Jackman R (1991) Unemployment: Macroeconomic Performance and the Labour Market. Oxford University Press Oxford

Lehmann H, Wadsworth J (2000) Tenures that shook the world: worker turnover in Russia, Poland and Britain. J Comp Econ 28:639-664

Marston ST (1985) "Two Views of the geographic distribution of unemployment". Q J Econ 100:57-79

Pannenberg M, Schwarze J (1998) Labor market slack and the wage curve. Econ Lett 58:352-354

Reza AM (1978) "Geographical differences in earnings and unemployment rates". Rev Econ Stat 60:201-208

Roland G (2000) Transition and Economics: Politics. MIT Press, Markets and Firms

Marx, K. (1993). Wage, Labor and Capital. USA: International Publishers Company

Shapiro C, Stiglitz JE (1984) "Equilibrium unemployment as a worker discipline device. Am Econ Rev 74:433-444, June 1984 Walsh PP, Whelan C (2001) "Firm performance and the political economy of corporate governance: survey evidence from Bulgaria, Hungary, Slovakia and Slovenia". Econ Syst 25/2:85-112

doi:10.1186/2193-9020-1-4

Cite this article as: Burke and Walsh: Regional earning disparities and the speed of transition: evidence from

Poland 1994-1997. IZA Journal of Labor \& Development 2012 1:4.

\section{Submit your manuscript to a SpringerOpen ${ }^{0}$ journal and benefit from:}

- Convenient online submission

- Rigorous peer review

- Immediate publication on acceptance

- Open access: articles freely available online

- High visibility within the field

- Retaining the copyright to your article

Submit your next manuscript at $>$ springeropen.com 